University of Pennsylvania Carey Law School

Penn Law: Legal Scholarship Repository

Faculty Scholarship at Penn Law

2020

\title{
The Opposite of Punishment: Imagining a Path to Public Redemption
}

\author{
Paul H. Robinson \\ University of Pennsylvania Carey Law School \\ Muhammad Sarahne \\ University of Pennsylvania
}

Follow this and additional works at: https://scholarship.law.upenn.edu/faculty_scholarship

Part of the Criminal Law Commons, Criminal Procedure Commons, and the Criminology and Criminal Justice Commons

\section{Repository Citation}

Robinson, Paul H. and Sarahne, Muhammad, "The Opposite of Punishment: Imagining a Path to Public Redemption" (2020). Faculty Scholarship at Penn Law. 2086.

https://scholarship.law.upenn.edu/faculty_scholarship/2086

This Article is brought to you for free and open access by Penn Law: Legal Scholarship Repository. It has been accepted for inclusion in Faculty Scholarship at Penn Law by an authorized administrator of Penn Law: Legal Scholarship Repository. For more information, please contact PennlawIR@law.upenn.edu. 


\title{
The Opposite of Punishment: Imagining a Path to Public Redemption
}

\author{
Paul H. Robinson* and Muhammad Sarahne ${ }^{* *}$
}

\begin{abstract}
The criminal justice system traditionally performs its public functions-condemning prohibited conduct, shaming and stigmatizing violators, promoting societal norms-through the use of negative examples: convicting and punishing violators. One could imagine, however, that the same public functions could also be performed through the use of positive examples: publicly acknowledging and celebrating offenders who have chosen a path of atonement through confession, apology, making amends, acquiescing in just punishment, and promising future law abidingness. An offender who takes this path arguably deserves official public recognition, an update of all records and databases to record the public redemption, and an exemption from all collateral consequences of conviction.
\end{abstract}

This article explores how and why such a system of public redemption might be constructed, the benefits it might provide to offenders, victims, and society, and the political complications that creation of such a system might encounter.

\section{TABLE OF CONTENTS}

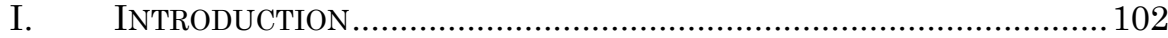

II. The Opposite of Punishment: The Power of Positive

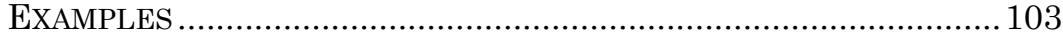

III. Who DESERVES PUBLIC REDEMPTION?........................................ 108

A. Confession and Apology .................................................... 108

B. Making Amends ............................................................... 108

${ }^{*}$ Colin S. Diver Professor of Law, University of Pennsylvania. The authors give special thanks for useful comments from Sarah Robinson, Adnan Zulfiqar, Ilya Rudyak, Stephen Garvey, Stephanos Bibas, and Kim Ferzan. (C) Paul H. Robinson

${ }^{* *}$ S.J.D., 2020, University of Pennsylvania Law School, and Assistant to the Deputy Attorney General, Ministry of Justice, Israel. 
C. Acquiescing in Deserved Punishment.

D. Avoiding Future Criminality

E. Exceptional Cases

IV. The CONSEqUENCES OF EARNING PUbLIC REDEMPTION ..............116

A. Public Ceremony of Recognition and Celebration .................116

B. Updating Records and Databases ......................................117

C. Removing Collateral Consequences of Conviction .................118

V. Public Redemption Versus Restorative Justice, Executive

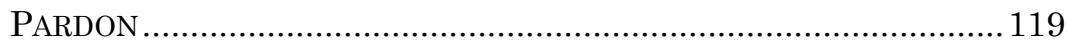

VI. MAKING THE PUBLIC REDEMPTION DECISION …………................... 125

VII. TwO KINDS OF POLITICAL OPPOSITION …….................................. 129

VIII. SUMMARY AND CONCLUSION ........................................................ 131

\section{INTRODUCTION}

News outlets provide a steady stream of stories about the arrest, conviction, and punishment of criminal offenders, and this media attention serves important societal interests. The coverage sends critical messages about the offense, the offender, and the criminal justice system: it reinforces the wrongfulness of the conduct, it condemns the wrongdoer for the choices made, and, as long as the punishment is just, it builds the criminal justice system's moral credibility with the community and thereby increases the likelihood of community deference, cooperation, and acquiescence, and the internalization of its norms. Under the right circumstances, such illustrations of punishment for wrongdoing can also provide a useful deterrent threat, ${ }^{1}$ which arises not just from the threat of imprisonment but also from the fear that the shaming and stigmatization of criminal conviction can injure an offender's social relations with family, friends, acquaintances, employers, and others. ${ }^{2}$

But one may wonder why these critical norm-shaping and behavioraltering functions of the criminal justice system need be vested exclusively in negative illustrations of punishment imposed. Might the same societal functions be effectively promoted through the use of positive illustrations: criminal wrongdoers reacting to their wrongdoing with sincere remorse and a genuine desire to atone? Perhaps making available an official path to public redemption could provide a series of

1. The regular reports of punishment of criminal wrongdoing can also provide a general deterrent threat. Less clear, however, is whether the specific formulation of criminal law rules can meaningfully manipulate this threat. PAUL H. ROBINSON, Distributive Principles of CRIMINAl LaW: Who SHould Be Punished How Much? 26123 (2008) [hereinafter DisTRIBUTIVE PRINCIPLES].

2. See id. at $175-78$. 
such positive examples that could effectively achieve these criminal law public functions at little cost.

What would be the benefits of a system of public redemption? What should be the prerequisites for such public recognition? What specific consequences should follow upon public redemption? What are the potential problems and complications in creating such a system? These are the questions taken up in this article.

\section{The OpPosite OF PUnishment: The POWER OF POSITIVE EXAMPLES}

Alan Melton had been laid off from his longtime job, and he started a lawn mowing business. ${ }^{3}$ For few months, however, the work was lean and bills were accumulating. ${ }^{4}$ Unable to pay those, Melton, who had never before committed a crime, robbed a convenience store and used the money to buy groceries, gasoline, and to pay for the funeral of his stepson. ${ }^{5}$ After two days thinking about it, he turned himself in to police. ${ }^{6}$ Melton explained that he knew he had done wrong and his conscience "got the better of him" and promised to make full restitution to the store. ${ }^{7}$

Charles Dutton began getting himself in trouble when he was thirteen years old and was in time convicted of a series of cases for manslaughter, possession of a deadly weapon, and fighting with a prison guard. ${ }^{8}$ After spending a few years in prison, he grabbed a book as he was heading for yet another round of solitary confinement-an anthology of plays-and in it discovered a humanity that he had never understood. ${ }^{9}$ Upon leaving solitary, he decided to take a new path in life. ${ }^{10}$ Instead of

3. Chris Proffitt, Remorseful Thief Turns Himself in for Robbery, WRTV INDIANAPOLIS (Dec. 2, 2015, 11:57 PM), https://www.theindychannel.com/news/local-news/remorsefulthief-turns-himself-in-for-armed-robbery.

4. Id.

5. Id.

6. Douglas Walker, Police: Robber Returns Stolen Cash, STAR PRESs (Dec. 1, 2015, 6:47 PM), https://www.thestarpress.com/story/news/crime/2015/12/01/police-bandit-retur ns-stolen-cash/76615648/.

7. Proffitt, supra note 3.

8. Equal Justice Initiative, Stories of Change \& Forgiveness, https://eji.org/ files/miller-media-kit-stories-of-change-and-forgiveness.pdf [hereinafter STORIES OF Change]; Ray Loynd, Charles Dutton Not a Prisoner of His Past: Stage: Former Convict Who Has Earned a Tony Nomination Takes on His Latest Challenging Role in August Wilson's 'The Piano Lesson', L.A. TIMES (Jan. 18, 1990, 12:00 AM), https:/l www.latimes.com/archives/la-xpm-1990-01-18-ca-419-story.html; Nina Totenberg, Do Juvenile Killers Deserve Life Behind Bars?, NPR (Mar. 20, 2012, 4:14 AM), https:// www.npr.org/2012/03/20/148538071/do-juvenile-killers-deserve-life-behind-bars.

9. STORIES OF CHANGE, supra note 8 .

10. Id. 
fighting the guards, he got approval to start a drama group. ${ }^{11}$ He focused on his education while in prison, receiving "his G.E.D. and then an Associate's Degree in theater." 12 Upon release, he attended college, moved on to Yale's drama school, and ultimately won an Emmy Award, as well as two Tony Award nominations. ${ }^{13}$ Now, more than forty years later, he thinks every day about the man he killed and wonders who he would have been. ${ }^{14}$

Raphael Johnson was convicted of second-degree murder. ${ }^{15}$ Most of the first half of his twelve years in prison was spent in solitary confinement because of continuing misconduct. ${ }^{16}$ Then, something in him shifted: "My exhaustion with this meaningless life propelled me to do everything in my power to change who I was and who I was becoming. . . . I began to detest my crime and I came to understand [the victim] and his family as human beings. I began to think of what I had put them through. ..."17 He wrote letters of apology and accepted the propriety of his imprisonment, as the starting point for a life where he could make amends. 18 "I focused on what I could do to right my wrong - to somehow atone for the innocent life I had taken. I began to concentrate on who I was going to be upon release rather than what I was going to do when released." 19 While in prison he became "a certified carpenter, plumber, electrician, and paralegal." 20 Upon release, he received his B.A. degree summa cum laude as well as a M.A.L.S. degree, worked with Goodwill Industries helping ex-offenders successfully re-enter society, and, using his street knowledge, helped Detroit police in organizing citizen patrols to search for specific suspects. ${ }^{21}$

\footnotetext{
11. Id.

12. $I d$.

13. Id.

14. Totenberg, supra note 8

15. Jonathan Oosting, Raphael Johnson: From Second-Degree Murder to Detroit City Council?, MLIVE (Aug. 19, 2019), https://www.mlive.com/news/detroit/2009/08/raphael_ johnson_from_seconddeg.html.

16. Statement of Raphael B. Johnson in Support of the Juvenile Justice Accountability and Improvement Act of 2007, H.R. 4300, EQUAL JUST. INITIATIVE, (Sept. 11, 2008), https:/ leji.org/news/statement-house-judiciary-committee-raphael-johnson-juvenile-justice-

reform [hereinafter Statement of Raphael B. Johnson]; STORIES OF CHANGE, supra note 8.

17. Statement of Raphael B. Johnson, supra note 16.

18. Id.

19. $I d$.

20. $I d$.

21. Id.; StORIEs OF ChANGe, supra note 8; George Hunter, Small Talk: Raphael B. Johnson Puts Prison Past Behind Him to Serve City, DeTRoIT News (Sept. 20, 2010), https:/ /eji.org/files/cdip-detroit-news-raphael-johnson-puts-prison-past-behind-him-09-20-10.pdf.
} 
There are thousands of cases like these, some less dramatic but equally sincere, ${ }^{22}$ even in the absence of a program providing a path to public redemption. Imagine a criminal justice system in which such cases of genuine remorse and atonement are officially recognized and celebrated. A formal public recognition program might at little cost have dramatic positive effects for offenders, for victims, and for society generally.

It would certainly be easy enough for a just-convicted offender to be preoccupied with the events that led up to arrest, conviction, and punishment-perhaps even natural to hold a grudge or to lament instances of perceived bad luck. Such a preoccupation with the past is all the more likely when the offender assumes that he or she has no real future. With the official criminal label, the person is permanently marked, and their future limited accordingly.

But if the criminal justice system produced not only a stream of criminal convictions and punishments but also highlighted a series of personal atonements resulting in public redemptions, the existence of a path to public redemption might alter some offender's perspective. First, it gives the offender a reason to think about his or her future rather than a preoccupation with the past. Second, it shows that their future is not irrevocably tragic. Public redemption, as the stream of examples shows, is indeed possible, even by a person who was once exactly in the situation in which the offender is now.

Setting more offenders on a path of atonement and redemption can also dramatically alter the fortunes of the offender's family, and indeed society generally. Whether or not the person ultimately reaches the point of a formal public redemption, positive steps in that direction are likely to increase the chances of a positive reintegration into society.

Even more importantly, such a system of public redemption producing a regular series of positive examples can have important broad societal effects. Every public redemption case sends an important set of

22. For examples of the wide variety of such cases already covered by the news media without any institutionalized publicity system (and without any existing system of encouragement), see for example, STORIES OF CHANGE, supra note 8, Tarshea Sanderson, With LEAP, I Found New Life After Prison, MiA. Found.: Found. BLOG (Feb. 15, 2018, 8:00 PM), https://miamifoundation.org/with-leap-i-found-new-life-after-prison/, JUST. POL'Y Inst. \& Child. \& Fam. Just. CTR., SECond Chances - 100 Years Of The Children's CourT: Giving Kids a Chance to MAKe A BeTter Choice (1999), http://www.cjcj.org/ uploads/cjcj/documents/100_years_of_the_childrens_court.pdf [hereinafter SECOND Chances], Randi Kaye, Some Felons Serve Time and Country, CNN: Anderson Cooper 360 (Feb. 6, 2007, 9:00 PM), http://www.cnn.com/CNN/Programs/anderson.cooper.360/ blog/2007/02/some-felons-serve-time-and-country.html, and Craig Guillot, Trucking Industry Looks to Felons to Plug Driver Shortage, TRUCKS.COM (July 24, 2017), https:// www.trucks.com/2017/07/24/trucking-industry-felon-drivers/. 
messages. First, the offender's public show of genuine remorse and wish to atone serves to reaffirm the importance of the social norm that was violated and serves to reinforce the shame and stigma associated with the violation.

Second, each case reinforces for members of the larger community that criminal offenders are indeed redeemable. That recognition can make it easier for all past offenders to be more easily accepted back into society. Third, a regular series of public redemptions can make community expectations more sophisticated: there is an important difference between the cynical and selfish offender whose present mindset is simply to escape punishment and look for another criminal opportunity and the offender who feels genuine regret for the wrong he or she has done. Having the community more aware of such differences in offenders teaches important lessons: not every offender deserves to be the recipient of sympathy but, on the other hand, as the series of public redemptions illustrate, many offenders respond to their offense and conviction in admirable ways. Every offender has choices to make about whether he or she will try to change their life path for the better and each offender ought to be judged according to those post-conviction and punishment choices.

There is an important difference between the predator and the repentant. Generalized anti-punishment attitudes ignore this meaningful difference. Society cannot exist without a system of punishment for wrongdoing. ${ }^{23}$ At the same time, unsophisticated lawand-order attitudes also ignore the predator-repentant difference. If one is genuinely concerned about doing justice, then one must be as concerned about punishing too much as punishing too little, and true remorse and repentance calls for reduced punishment; more on this later. ${ }^{24}$

In addition to this valuable societal-signaling function, a system of public redemption can promote reintegration of the redeemed offender. Such an admirable achievement deserves special support, perhaps in the form of scholarships for training or education or preferences in hiring. Also, a system of public redemption can provide useful political and social "cover" to individuals, companies, and institutions who want to support redeemed offenders but who are hesitant to do so because hiring an offender may risk the public ire of some.

23. See Paul H. Robinson \& Sarah M. Robinson, Pirates, Prisoners, and LePers: LESSONS FROM LIFE OUTSIDE THE LAW 32-50 (2015) [hereinafter PIRATES].

24. See infra notes 54-62 and accompanying text. 
On becoming pregnant at fourteen, Michelle Jones' mother beat her, contributing to the baby being born disabled. ${ }^{25}$ Young, frustrated, alone, and caring for the disabled infant, Jones beat the baby and left it alone, returning several days later to find him dead. ${ }^{26}$ While incarcerated, Jones trained to become certified as a paralegal and earned a bachelor's and a master's degree. ${ }^{27}$ As her twenty years of incarceration ended, she was accepted to Harvard's Ph.D. program. ${ }^{28}$ In her application, she wrote, "I have made a commitment to myself and [my son] that with the time I have left, I will live a redeemed life, one of service and value to others." 29 Before she could start at Harvard, the University withdrew their offer out of fear of the negative publicity it might generate. ${ }^{30} \mathrm{~A}$ grant of public redemption by the state that initially convicted Jones would have given Harvard some protection from the public criticism it feared. ${ }^{31}$

25. See Belinda Luscombe, We Need to Forgive the College-Bound Mother Who Killed Her Child, Time (Sept. 14, 2017, 6:37 PM), http://time.com/4941576/harvard-nyu-michellejones/.

26. See id.

27. Eli Hager, From Prison to PhD: The Redemption and Rejection of Michelle Jones, N.Y. Times (Sept. 13, 2017), https://www.nytimes.com/2017/09/13/us/harvard-nyu-prisonmichelle-jones.html.

28. Id.

29. $I d$.

30. Id.; Luscombe, supra note 25.

31. See also Just Reward: How the Past Haunts One Illinois Mother Searching for a Second Chance, ILL. POL'Y, https://www.illinoispolicy.org/story/just-reward-how-the-pasthaunts-one-illinois-mother-searching-for-a-second-chance/ (last visited Nov. 2, 2020) [hereinafter Searching for a Second Chance]. Lisa Creason was convicted of a forcible felony for the attempted robbery of a Subway store. Id. She freely admits that what she did was wrong and that she needed to take a new path in life. Profiling: Lisa Creason, CiTIZEN (Aug. 30, 2017, 12:00 PM), https://citizennewspapergroup.com/news/2017/aug/30/profiling-lisacreason/?page $=3$. Upon leaving prison, she started a nonprofit to fight youth violence. Searching for a Second Chance, supra note 31. She went back to school and completed a nursing degree while raising her children and working as a certified nursing assistant. Id. Her goal was to become a registered nurse $(\mathrm{RN})$, which would allow her to advance in her skill set and earn a better income. $I d$. But Illinois law did not allow felons to become RNs. Id.; Theresa Churchill, Woman Asks Second Chance to be Nurse, PHILA. TRIB. (Oct. 23, 2015), https://www.phillytrib.com/woman-asks-second-chance-to-be-nurse/article_c582b00 6-ab98-5df2-8cc9-60f829d45361.html.

For another example, consider the case of James Short, who was convicted for various assaults and burglaries. SECOND CHANCES, supra note 22, at 79-80. While serving time at a detention facility he came to understand that this was not the person he wanted to be. See id. at 81. "I knew better, I just did wrong." Id. He became a barber and tried to become a fireman. $I d$. at 82 . Despite turning his life around, his record followed him, creating obstacles to his attaining his goals and nearly preventing him from becoming a firefighter. $I d$. Through perseverance he worked his way around the barriers and built a heroic career in the D.C.'s Fire Department. Id. In time he became the Captain of the District of Columbia Fire and Emergency Services Department. Id. 


\section{Who Deserves PUblic REDEMPtion?}

The central feature justifying public redemption is that the offender feels genuine remorse and has a true desire to atone for his or her criminal wrongdoing. But there is also value in having these feelings manifested in specific conduct, both to objectively confirm the sincerity of the offender's atonement motivation and for the benefits that such outward making-amends conduct can bring to victims and can bring to society by advertising positive examples.

\section{A. Confession and Apology}

An offender who feels genuine remorse and a true desire to atone will themselves want to confess and offer a sincere apology. Ideally, the offender would want to do this even if law enforcement has not yet identified them as an offender or been able to pull together a prosecution case. On the other hand, not every genuinely remorseful offender will immediately come to these feelings. A person can have an epiphany about their life path at any time. An offender may not reach a state of true remorse until after losing at trial and serving some time in prison. As long as the feeling is genuine, there ought to be no time constraint.

It is probably true, however, that the later in the process the confession and apology occur, the more skeptical people are likely to be about the sincerity of the feelings and the more likely they are to assume that the confession and apology are simply a next obvious step in a calculated plan to minimize punishment. Where the confession and apology are made early in the process, especially where it creates serious legal consequences for the offender, such conduct tends to provide on its face, compelling evidence that the remorse is genuine.

\section{B. Making Amends}

An offender who is genuinely remorseful for the offense will want to make amends, whether the victim of the offense is a particular person or a group, or society generally. Making amends will not always be possible but a sincere desire to do so can be shown in doing whatever is possible within the limitations of the offender's situation and abilities.

Where there is an identifiable victim, the offender ought to try to make up for not only physical but also emotional injury. After stealing from the home of a neighbor, an offender could restore the property and acknowledge to the victim that he understands the wrongness of the violation. That conversation may be able to do much to reduce the victim's generalized fear caused by the break-in. 
Some crimes may have a large group of unidentified victims but acts of making amends are still possible. A former member of a hate-group could actively work to help those people he once sought to vilify. TJ Leyden was an up-and-coming star in the White Supremist movement when, with the help of his disabled mother, he rethought the life path he had chosen. ${ }^{32}$ He rejected the movement and its hate and went to work for the Task Force Against Hate at the Simon Wiesenthal Center, a Jewish human rights organization in Los Angeles that fights antiSemitism and other forms of racism. ${ }^{33}$

Other offenses may be harms against society generally. But here too it is still possible to make amends. A violent gang member could join with the local community center to give more meaningful options to the young people of the community. Offenders with greater abilities could do more. Bruce Karatz was the chief executive of KB Home when he was convicted of felony charges "related to the backdating of stock options." 34 Unrelated to the punishment imposed by the court, Karatz joined a group dedicated to giving felons a chance at redemption through various community initiatives and used his financial and organizational skills to significantly increase the activities that the group sponsored. 35 "I just wanted to feel that I was doing something meaningful." 36

An offender whose offense has no specific injured party can nonetheless undertake forms of atonement that are primarily symbolic. A white-collar criminal may not be able to restore stolen assets to his victims, but he could give up his weekends to work in soup kitchens.

Making amends also may include helping society by helping to bring co-conspirators or accomplices to justice. The repentant robber could identify to authorities' people who sell stolen goods. The former member of a hate-group could help authorities better understand the operation of the hate-group she left. A man who left the gang life might use his knowledge to help authorities solve local murders.

32. Duke Helfand, Ex-Skinhead's Unlikely Alliance, L.A. Times (Aug. 12, 1996, 12:00 AM), https://www.latimes.com/archives/la-xpm-1996-08-12-me-33587-story.html; TJ Leyden, TJ Leyden, THE ForGIVENESS PROJECT, https://www.theforgivenessproject.com/ stories/tj-leyden/ (last visited Nov. 2, 2020).

33. Leyden, supra note 32.

34. Marcus Baram, Homeboy Industries: Turning Lives Around, One Gang Member at a Time, HuffPost (Jan. 6, 2012, 4:03 PM), https://www.huffpost.com/entry/homeboyindustries_n_1189946.

35. Id.

36. Id. 


\section{Acquiescing in Deserved Punishment}

An offender who is truly remorseful will willingly acquiesce in receiving the punishment he or she deserves. Maneuvering for a punishment reduction suggests that the remorse is not genuine but more likely a false expression motivated by self-benefit. True remorse means accepting the propriety of one's deserved punishment. Jeffrie Murphy suggests that "[r]epentant people feel guilty, and a part of feeling guilty is a sense that one ought to suffer punishment. Thus, guilty and repentant people may well seek out, or at least accept willingly, the punishment that is appropriate for their wrongdoing." ${ }^{37}$ A truly repentant offender would normally deem his suffering punishment proper. 38

John Williams was eighteen when he shot six police officers, one of whom died. ${ }^{39}$ In prison he earned two bachelor's degrees, in sociology and theology, and is currently working towards his master's degree in theology. 40 "There has not been a day that has passed during these forty years that I have not had to face the fact that I have taken the life of another human being,' he wrote." ${ }^{41} \mathrm{He}$ declined to participate in parole hearings because he felt that it was proper for him to be in prison. ${ }^{42}$ (More recently, one of the officers he shot reached out to him and they began a conversation. ${ }^{43}$ With the officer's support, Williams has now agreed to participate in his next parole hearing. ${ }^{44}$ )

Bart Whitaker solicited the murder of his entire family. ${ }^{45}$ His father survived the attack and then spent years trying to have his son's death sentence reduced to life. ${ }^{46}$ The father has forgiven his son, visits him regularly in prison, and walks him through all his difficult emotional

37. Jeffrie G. Murphy, GetTing Even: Forgiveness And Its Limits 46 (2003) (emphasis omitted).

38. See id. at 51-52. Murphy also argues that a remorseful offender may ask for mercy or reduction in sentence in order to better pursue good deeds in the remainder of his life and warns against assuming that all such expressions or desires are driven by self-interest and meant to avoid deserved punishment. Id. at 52.

39. Anneta Konstantinides, Former Baltimore Cop Befriends Man Who Shot Him and Killed One of His Colleagues 40 Years Ago - and is Even Fighting for His Early Release, DAILY MAIL (Nov. 1, 2016, 1:32 PM), https://www.dailymail.co.uk/news/article-3886504/ Former-Baltimore-cop-fights-release-man-shot-40-years-ago.html.

40. Id.

41. Id.

42. Id.

43. Id.

44. Id.

45. Barry Leibowitz, Book 'Em: Murder by Family, CBS News (Aug. 24, 2009, 9:13 AM), https://www.cbsnews.com/news/book-em-murder-by-family/.

46. Id. 
times. ${ }^{47}$ The father worked tirelessly to prevent his son's execution because "I want him to have as much time as possible to do good works ... even though it will all have to be done from within prison." 48 The father does not question that his son should accept the punishment he deserves. 49 " $[\mathrm{H}]$ e owed it to everyone to take his medicine. . . ." 50

While it is true that genuine atonement is not possible without acquiescing in deserved punishment, there are three important caveats relevant here. First, an offender should never acquiesce in punishment that is more than deserved, and there are many aspects of current criminal law that press unjust punishment. Second, in many instances the existence of genuine remorse and a wish to apologize and atone may themselves reduce the offender's blameworthiness and, therefore, the extent the punishment deserved. Third, it is appropriate to give punishment credit for self-punishment in the process of a genuine effort to atone. As to the first point-an offender ought never acquiesce in more punishment that is deserved-the criminal justice system must abide by a principle of strict proportionality between offender blameworthiness and punishment imposed. As Jeffrie Murphy puts it, a "person who commits a strict liability offense ... may have much to regret, but since he acted without moral fault, nothing to be remorseful about." ${ }_{51}$

Unfortunately, many current law doctrines violate the blameworthiness proportionality principle, such as three-strikes statutes, felony murder, strict liability offenses, the failure to provide deserved mitigations, etc., and are designed instead to serve some crimecontrol purpose at the expense of just punishment. No offender need acquiesce in over-punishment pursuant to these unjust doctrines. ${ }^{52}$ (Note, however, that some doctrines have the effect of reducing or preventing punishment for reasons other than reduced blameworthiness - such as the exclusionary rule or a variety of non-exculpatory defenses. ${ }^{53}$ Pressing these legal doctrines is not acquiescing in deserved punishment.)

As to the second point-genuine remorse and voluntary apology and confession are behaviors that are likely to reduce deserved punishmentthe support for this conclusion is different depending upon which of two

47. Id.

48. Kent Whitaker, MURDer BY FAMILY 180 (2008); Leibowitz, supra note 45.

49. See Leibowitz, supra note 45.

50. WHITAKER, supra note 48 , at 177.

51. Jeffrie G. Murphy, Repentance, Punishment and Mercy, in RePentance: A Comparative Perspective 143, 149 (Amitai Etzioni \& David E. Carney eds., 1997).

52. Paul H. Robinson \& Michael T. Cahill, LaW Without Justice: Why CRiminal Law Doesn't Give People What They Deserve 117-36 (Oxford Univ. Press 2006).

53. Id. at $137-85$. 
alternative conceptions of desert one adopts: deontological desert or empirical desert. ${ }^{54}$ The first is calculated by moral philosophers deriving conclusions by reasoned analysis from principles of right and good. ${ }^{55}$ The second is determined by social psychologists in studying ordinary people's shared judgments of justice. ${ }^{56}$

As to empirical desert, the empirical studies make it clear that there is good support among ordinary people for seeing reduced blameworthiness in genuine remorse, sincere apology, and public acknowledgment of guilt. ${ }^{57}$ And the extent of the support increases when these factors appear together. ${ }^{58}$ This is true for minor offenses and victimless crimes as well as for homicide offenses. ${ }^{59}$

As to deontological desert, in contrast, there remains debate on the issue. The traditional view took an offender's blameworthiness as settled upon completion of the offense, but some deontological desert arguments would lead to a conclusion of reduced punishment for subsequent remorse and the desire to atone. ${ }^{60}$ For example, some writers support a "duty view of punishment," under which criminal punishment is justified on the grounds that all offenders are morally obligated to contribute to the general deterrence of crime with criminal punishment being the way this moral obligation is satisfied. ${ }^{61}$ Another writer suggests that if we adopt this theory of punishment, it is possible to conclude that remorseful offenders deserve mitigated sentences because their remorseful actions, like pleading guilty and apologizing ease their burdens on the criminal justice system, which contributes to general deterrence and thereby fulfills part of their moral obligation. ${ }^{62}$

In a different kind of deontological desert argument-one of a more evidentiary nature - one could argue that genuine feelings of remorse serve to alter after-the-fact our assessment of the offender's conduct and

54. Paul H. Robinson, Competing Conceptions of Modern Desert: Vengeful, Deontological, and Empirical, 67 CAMBRIDGE L.J. 145 (2008).

55. DISTRIBUTIVE PRINCIPLES, supra note 1 , at 139 .

56. See id. at $138-40$.

57. See Paul H. Robinson et al., Extralegal Punishment Factors: A Study of Forgiveness, Hardship, Good Deeds, Apology, Remorse, and Other Such Discretionary Factors in Assessing Criminal Punishment, 65 VAND. L. REV. 737, 781-90 tbls.4-8 (2012) [hereinafter Robinson, Extralegal Punishment Factors].

58. See id. at 782-83 tbls.5, 6 . Note the difference between the findings regarding XPF's $1,2,3$ and 4 in tables 5 and 6 .

59. See id. at 785-88.

60. See Distributive PRINCIPLES, supra note 1 , at 15 .

61. See Victor Tadros, The Ends of Harm: The Moral Foundations of Criminal LAW 265-92 (2011).

62. Benjamin Ewing, Mitigation Factors: A Typology, in The Palgrave HandBook of APPLiEd ETHics AND THE CRIMINAL LAW 423-42 (Larry Alexander \& Kimberly Kessler Ferzan eds., 2019). 
culpability at the time of the offense. That is, we may take the subsequent feelings as relevant in interpreting (or reinterpreting) what the offender must have had in his mind at the earlier time of the offense conduct.

Jeffrie Murphy makes a somewhat analogous argument. He distinguishes grievance retributivism (punishment as "deserved for responsible wrongful acts") and character retributivism (desert as a function of not only one's wrongful acts, but also the ultimate state of his character). ${ }^{63} \mathrm{He}$ contends that while repentance seems not to have a central role in grievance retributivism, as the wrongfulness of a conduct is typically not affected by a later repentance, it can play a crucial role in character retributivism, "for a repentant person seems to reveal a better character than an unrepentant person," and therefore deserves less punishment than the latter. 64

As to the third point above-self-punishment through voluntary acts of atonement can in some instances properly count as part of an offender's official punishment-it is true that many voluntary acts of atonement will be dramatically different from the standard punishment forms of imprisonment or fine. But that ought not be a stumbling block to counting atonement conduct as punishment. Desert typically requires only a certain total amount of punishment, not a particular method. ${ }^{65}$ Taking into account the different punishment "bite" of different methods can allow deserved punishment to be imposed in any of a wide array of methods or combination of methods. Desert requires only that the total punitive "bite" of all of the different forms of punishment, adjusted for the unique "bite" effect of each, must total the total punishment deserved. 66

It can be argued that an offender ought not to get punishment credit for suffering that is not officially imposed by society specifically as punishment for the violation. ${ }^{67}$ Thus, for example, an offender who hurts

63. MURPHY, supra note 37 , at 43.

64. Id. at $43-44,52$.

65. See Distributive Principles, supra note 1, at 50-51; PAUl H. RoBinson, INTUITIONS OF JUSTICE AND THE UTILITY OF DESERT 165-66 (2013) [hereinafter INTUITIONS OF JUSTICE].

66. INTUITIONS OF JUSTICE, supra note 65 at 165-66.

67. R.A. Duff, for example, advocates understanding punishment in communitarian terms, as a communication act between the community and the offender who defied one of its shared norms. See MURPHY, supra note 37, at 48. The separation from the community that the wrongdoer values and to which he wishes to return is the suffering he would undergo and experiencing the pain of such separation would make him realize the appropriateness of that separation and pursue reconciliation with the community. $I d$. The purpose is to replace the compulsory penance with a voluntary penance-a sincere act of reattachment to the community values, allowing the reintegration of the wrongdoer into the community. Id. This view seems inspired by the Platonic notion of moral improvement 
himself in the course of committing an offense ought not get credit for the injury as part of his punishment.68 Nor should an offender get punishment credit because his conduct causes him to lose his job or tarnishes his professional reputation, as Murphy points out. 69

One might argue that voluntary self-punishment similarly ought to be excluded. However, in an instance of genuine remorse and a sincere effort to atone, the self-punishment is tied directly to and is meant to be deserved punishment for the offense. It is done by an offender on behalf of the society in large part to acknowledge the propriety of punishment, so it is more appropriate to give it punishment credit.

Certainly, the system ought not allow clever offenders to seek to preempt undesirable forms of punishment by arranging beforehand to undertake more desirable forms of punishment. Strategic selfpunishment is not remorseful self-punishment. If the conduct of voluntary atonement is more comfortable for the offender or less costly to the offender than the punishment that the court would have imposed, then its "punishment credit" should be discounted accordingly. Indeed, if the supposed atonement conduct does not have a genuine atonement motivation, then it ought not qualify the offender for public redemption at all.

Whether an offender gets punishment credit for self-punishment (or for making-amends conduct) will be a matter for the sentencing judge for the original offense, not the redemption jury. However, the issue may come up in the redemption context where an offender litigated the issue earlier (seeking punishment credit for self-punishment) and the issue at the redemption hearing is whether such earlier litigation violates the requirement that the offender acquiesced in deserved punishment. The

as the primary value that should govern punishment, under which punishment is a device to transform the offender's character from a state of vice to a state of virtue. See id. at 45 . This clear division between the punishment imposed by the community and voluntary selfpunishment, which is triggered by the former, implies that acts of atonement do not count as part of the official punishment inflicted by the society.

68. There is some mixed support for the notion that a person's punishment should be reduced if he has already suffered substantially because of his offense. See Robinson, Extralegal Punishment Factors, supra note 57, at 782. There, in Table 5, the findings in row 6 indicate that the percentage of responses from participants of the study displaying reduction in punishment amount due to the fact that the offender has already suffered from his own offense is relatively low, across all case scenarios, and are significantly lower than the popularity of true remorse, acknowledgment of guilt, and apology, immediately after offense as shown in the first row of the same table. Id. It should be noted, however, that an offender's suffering from his offense-for example, he accidentally kills his child by leaving him in a hot car-can be relevant on another issue of the public redemption program. Specifically, where such suffering occurs, it can as an evidentiary matter increase the likelihood that an offender's claim of genuine remorse is more likely to be believed.

69. MURPHY, supra note 37, at 51. 
offender should be able to argue that such earlier litigation did not violate the acquiescence requirement.

\section{Avoiding Future Criminality}

A final prerequisite for public redemption ought to be for an offender to publicly commit to a life that avoids future criminality. Any offender who responds to his or her offense with confession, sincere remorse, making amends, and acquiescing in deserved punishment is someone who will almost necessarily have genuinely committed themselves to a future of law abidingness, but it might be useful to crystallize those feelings in a formal written promise. That public promise can help remind the offender of the commitment when situations of temptation later arise. It can also be useful in establishing public support for a system of public redemption.

The bare statement of the promise ought not be enough. The promise ought to be backed by action: the offender taking the steps necessary to avoid a recurrence of the factors that contributed to the past criminality. This may mean kicking an addiction, getting the training needed for successful employment, avoiding some kinds of persons or situations, or a variety of other sorts of preemptive behavior.

It would be appropriate to adopt a rule that subsequent criminality can void the public redemption and its consequences. This does not mean that the offender is thereafter barred from attempting to gain public redemption in the future but only that the offender must start over again in order to earn that status. Some forms of post-redemption criminality would be more damaging to a second public redemption request than other forms of post-redemption criminality. An offender may be genuinely remorseful about embezzling from his employer and receive a public redemption for it. That prior history may be seen as having only limited relevance when ten years later the same person accidentally kills a pedestrian while driving drunk and claims to be genuinely remorseful about it.

\section{E. Exceptional Cases}

Should a public redemption ever be granted in the absence of these four prerequisites-confession and apology, making amends, acquiescence in deserved punishment, and avoiding future criminality? Part $\mathrm{V}$ urges that the public redemption decision be made by a jury and no doubt juries will exercise some flexibility in interpreting whether the prerequisites are satisfied in a given case. But while that ability to "fudge" may be useful, it would seem inadvisable to go further to formally 
allow exceptions to the four prerequisites because doing so risks undermining the credibility of the public redemption award. It would be easy to see how making the prerequisites only advisory for the redemption jury could slide into a habit of granting the public redemption award in an increasing number of borderline cases, reducing its reliability and thereby undermining its purpose.

It may be true that there will be some offenders who do genuinely deserve public redemption even though they do not satisfy the four prerequisites. And it may be that over time, with enough experience, one could confidently alter the stated requirements in a way that would capture these deserving exceptional cases without including undeserving cases. But with no present experience in reviewing and evaluating possible redemption cases, it would be difficult today to anticipate what kinds of special exceptions to recognize.

\section{The Consequences of EARNing PUBLic REDEMPTION}

If an offender shows genuine remorse and a sincere desire to atone and manifests such views through the conduct described above, what should be the result? It is argued here that at least three consequences should naturally follow: a public ceremony recognizing and celebrating the offender's public redemption, the revision of all records and databases to show the official recognition, and the removal of all collateral consequences of conviction. These are not offered as incentives, although they might help provide additional encouragement for an offender who is inclined toward remorse, confession, apology, making amends, and future law abidingness. They are offered instead as the logical result that follows when an offender has through his or her conduct earned public redemption.

\section{A. Public Ceremony of Recognition and Celebration}

Achieving public redemption is certainly an event worth celebrating, and such a ceremony can send important public signals for the offender, family, friends and acquaintances, other offenders, and the community at large.

First, it gives the offender the public recognition he or she deserves. Second, it formally signals to family, friends, acquaintances, prospective employers, and others that this important milestone has been reached. As long as the ceremony is conducted with the same solemnity and publicity as the original conviction, it can counterbalance the public condemnation inherent in that conviction. 
Another important function performed by the ceremony may be the signal it sends to other offenders. Every case of public redemption provides an important example of how a shamed offender really can regain the acceptance and admiration of the community.

Perhaps most important is the message that such a ceremony sends to the public generally. That this offender would make the choice and undertake the sacrifices needed to obtain public redemption serves to reinforce the wrongfulness of the original offense and to reinforce the societal norms against such conduct. The extent of the sacrifice confirms the seriousness of the wrongdoing.

But the public redemption example may speak even more broadly, beyond the strict bounds of criminal law, to set a shining example of the special value and admirability of genuine remorse and atonement even for wrongdoing short of criminality. In other words, these cases of public redemption of offenders can remind us all how best to live our lives in all its facets.

\section{B. Updating Records and Databases}

There is good reason for jurisdictions to keep records of past criminality. They help identify persons who may need special watching. They may help in giving a fuller picture of the offender in determining how to punish for a future offense. They may signal the need for a continuing limitation on an offender's rights after completing his sentence. (More on such collateral consequences of conviction in the subsection below.) But all of these reasons make it important to update the record, wherever it might appear, to indicate that a public redemption has been earned for the past offense. An offender who has been publicly redeemed is a person who no longer deserves special watching, or at least no more than the typical non-offender.

Some people might argue that public redemption ought to result in expungement of the original offense, but there are good reasons to resist this suggestion. First, a criminal justice system that tries to hide facts from the public is one that will in the long-run lose credibility, as a system that simply cannot be trusted to be honest and forthright. The better approach is to tell the whole story, not to try to hide part of it.

Relatedly, even when an official conviction is expunged, there remains an enormous amount of other information by which a past conviction can become easily discovered-arrest reports, records of court appearances, judicial orders, and correctional records. ${ }^{70}$ Expunging a

70. See Kristin Brown Parker, The Missing Pieces in Federal Reentry Courts: A Model for Success, 8 DREXEL L. REV. 397, 422 (2016). 
conviction does little or nothing to destroy this mountain of material. The safer course toward creating a good record for the offender is to add the award of public redemption in every place where the conviction has been recorded. Once it is made very public, it can stand as a guard of the offender's reputation no matter what past record materials appear.

Finally, an offender who earns public redemption deserves quite a bit more than pretending the earlier offense never occurred. Earning public redemption gives us important positive information about the redeemed offender: he has dealt with the stigmatizing condemnation of criminal conviction in an admirable way. It tells us something about his character that we cannot know about the non-offender unless the non-offender is similarly tested. We are not simply pretending that the offender did not commit the offense but rather celebrating the fact that he or she has voluntarily chosen to atone for it.

\section{Removing Collateral Consequences of Conviction}

A criminal conviction carries with it a wide range of collateral consequences beyond the formal punishment of imprisonment, fine, community service, or other standard sanction. A wide variety of aspects of an offender's life may be affected, including restrictions on voting, business and occupational licensing, immigration and travel, housing and residency possibilities, registration and reporting requirements, family and domestic rights, motor vehicle licensing, employment and volunteering opportunities, educational grants and student aid, military service, jury service, eligibility for public welfare benefits and food stamps, and more..$^{71}$

The justification for these collateral consequences rests upon the need to punish the offender and upon judgments about the offender's character that suggest he or she is more dangerous or less trustworthy than a non-offender. But an offender who has earned public redemption is a person to whom neither of these justifications apply. The offender has already received the punishment deserved, and indeed acquiesced in it. And, the offender has shown us something positive about his or her current character by having demonstrated genuine remorse and voluntary acts of atonement.

71. Michael Pinard, An Integrated Perspective on the Collateral Consequences of Criminal Convictions and Reentry Issues Faced by Formerly Incarcerated Individuals, 86 B.U. L. REv. 623, 635-36 (2006); Michael Pinard \& Anthony C. Thompson, Offender Reentry and the Collateral Consequences of Criminal Convictions: An Introduction, 30 N.Y.U. REV. L. \& Soc. Change 585, 586-87 (2006); Michael Pinard, Reflections and Perspectives on Reentry and Collateral Consequences, 100 J. CRIM. L. \& CRIMINologY 1213, 1214-15 (2010). 
Recall that the primary test for public redemption is whether the offender's expressions of remorse, acquiescence in deserved punishment, and desire to atone are truly voluntary and sincere, not simply driven by a calculation to gain some benefit or escape some sanction. Here is where that guiding principle pays off. If we have followed that principle, we have little reason to worry that the offender's redemption is undeserved or that he or she cannot be trusted.

If there is some special reason to be worried that some particular kind of collateral consequence might be important to maintain, at least temporarily-perhaps to help the offender avoid backsliding-a remorseful offender himself or herself might support delaying the removal of that particular collateral consequence-such as one prohibiting the consumption of alcohol-for some period of time. ${ }^{72}$ Such a suggestion in redemption application could itself be persuasive evidence for the redemption jury that the offender's remorse and desire to atone and remain law-abiding is indeed genuine.

\section{Public Redemption Versus Restorative Justice, EXECUTIVE PARDON}

The proposed system of public redemption and the currently-existing programs of restorative justice have some similarities but also some fundamental differences. Most obviously, restorative justice processes are designed to adjudicate the offense itself, while the proposed public redemption program would serve only to provide redemption and reintegration after the normal criminal adjudication and punishment are complete. On the other hand, the two do have some common features and are motivated by some similar goals. Both go well beyond an assessment of the facts surrounding the offense. Both imagine a disposition of the case in which the offender may attempt to make some amends to the victim. Both claim to promote reintegration and acceptance of the offender back into society.

At bottom, however, the two are fundamentally different, and at odds, in what they seek to achieve and how they do it. First, as originally envisioned by its creators, such as the likes of John Braithwaite,

72. Restricting or delaying the removal of a certain collateral consequence may be justified, however, only if it is meant to promote the offender's successful reintegration (like prohibiting the consumption of alcohol), and not, for example, because the collateral consequence involves a "scarce and costly community resource" (like tax funded legal education) rendering its denial not "comparably unconscionable" as Murphy suggests. MURPHY, supra note 37, at 53-54. 
restorative justice is primarily an anti-punishment mechanism. ${ }^{73}$ Public redemption, in contrast, wholeheartedly accepts the importance of imposing just punishment, and indeed sets as one of its prerequisites that the offender himself or herself voluntarily acquiesce in the imposition of just punishment. While some academic elites may think punishment is an outmoded notion, there is a strong consensus among ordinary people, which is the group to which the criminal justice must address itself, that the imposition of just punishment, no more and no less than is deserved, is an essential feature of a just and orderly society. ${ }^{74}$

Ironically, restorative justice programs probably survive only because in practice they do not achieve the anti-punishment purpose that their originators had hoped for. Because ordinary people have strong intuitive judgments about the importance of doing justice, 75 the restorative justice group decisions are likely to commonly closely track notions of empirical desert. The larger the decision-making group, the more likely the resulting decision will reflect ordinary people's shared judgments of justice. ${ }^{76}$ (The tragedy is that the anti-punishment history of restorative justice has ended up limiting its application to narrow areas such as misdemeanor offenses and juvenile justice, when it could have produced great benefits if used in the adjudication of more serious offenses. ${ }^{77}$ )

A second and more important difference between restorative justice and public redemption is this: the former generally ignores the critical public signaling function of the criminal justice system, while the latter has public signaling at its core. The primary focus of restorative justice is to settle things between the parties, as if criminal law were simply another form of civil action. In fact, the criminal law has an essential public function, perhaps its most important function-to promote and shape societal norms ${ }^{78}$ - a function that is completely lost by the private adjudication typical of restorative processes.

Relatedly, restorative justice does not actually reintegrate an offender into society but only into the offender's close personal group who

73. See John Braithwaite, A Future Where Punishment is Marginalized: Realistic or Utopian?, 46 UCLA L. REV. 1727, 1743 (1999) (classifying restorative justice as competing with punitive justice).

74. See PIRATES, supra note 23, at 32; IntUITIONS OF JUSTICE, supra note 65, at 89-90, 209-15; DisTRIBUTIVE PRINCIPLES, supra note 1, at 217-19.

75. See Distributive PRINCIPLES, supra note 1, at 1-6; INTUITIONS OF JUstice, supra note 65 , at $5-94$.

76. Paul H. Robinson, The Virtues of Restorative Processes, the Vices of "Restorative Justice”, 2003 UTAH L. REV. 375, 381-82 (2003).

77. Id. at 384-87; Paul H. Robinson, Restorative Processes \& Doing Justice, 3 UNIV. ST. THomas L. J. 421, 428-29 (2006).

78. DistRIBUTIVE PRINCIPLES, supra note 1, at 147. 
participate in or are personally familiar with the restorative process by which the case is privately resolved. Restorative justice would have to shed its private nature if it were to be able to do something more than personal accommodation.

In contrast, the public redemption proposal is designed to speak to the larger society, which it can do because it operates publicly, ends with a public announcement, takes account of broad societal interests in its decisions, and is designed and constructed specifically to influence the larger society through public signaling. The public redemption process is in some sense a form of societal restorative justice, rather than the individual, private restorative justice of current restorative processes.

In some respects, similar to restorative processes are what have been called transitional justice processes, which as the name implies are commonly used in transitional periods following lengthy conflicts or repressions, and are designed to address longtime systemic abuse of human rights and institutionalized wrongdoing. ${ }^{79}$ Among these processes one may find truth commissions, criminal prosecutions, public memorials, etc. ${ }^{80}$ For example, the Truth and Reconciliation Commission of South Africa, assembled after the fall of the apartheid regime, granted amnesty to many individuals who engaged in human rights violations. ${ }^{81}$

There are some similarities between transitional justice and the proposed public redemption system in that both give value to public confession and apology and both may exempt offenders from the standard consequences of criminal conviction going forward. The two are also fundamentally different in that transitional justice often foregoes deserved punishment while public redemption demands it. (Also, some transitional justice methods are contrary to the reintegration goal, such as prohibiting individuals formerly affiliated with the repressive regime from serving in certain public positions.) ${ }^{82}$

Public redemption is also similar to but fundamentally different from the current exercise of the executive clemency or pardon power. Both public redemption and clemency operate after the criminal adjudication process is complete, although a grant of clemency or pardon may shortcircuit some of the punishment imposed. Some grants of executive clemency or pardon may be motivated by the kinds of reasons that would support to a grant of public redemption. And in those cases, publicity

79. Lesley Wexler et al., \#Metoo, Time's Up, and Theories of Justice, 2019 U. ILL. L. REV. 45, 90-91 (2019).

80. Id. at 91 .

81. Desmond Tutu, Truth and Reconciliation Commission, South Africa, ENCYClOPEDIA BRITANNICA (Feb. 4, 2019), https://www.britannica.com/topic/Truth-andReconciliation-Commission-South-Africa.

82. Wexler et al., supra note 79 , at 91. 
about the clemency or pardon and the reasons for it might serve some of the public-signaling functions sought to be promoted by the public redemption system.

Again, however, existing clemency or pardon programs are fundamentally different from the proposed system of public redemption. First, while it is conceivable that an offender is given clemency or pardoned because he or she has essentially met the requirements that call for an award of public redemption, the current clemency-pardon system has no such requirement. ${ }^{83}$ Indeed, it has just the opposite reputation. ${ }^{84}$ Most executive clemency or pardon systems have little or no fixed criteria but rather are left to the vast unguided discretion of the executive. ${ }^{85}$

In 1983, Marc Rich and his partner were indicted on sixty-five criminal counts, including income tax evasion, wire fraud, racketeering, and trading with Iran during the oil embargo (at a time when Iranian revolutionaries were still holding American citizens hostage). 86 The charges could have yielded a sentence of more than 300 years in prison but Rich fled to Switzerland. ${ }^{87}$ His companies eventually pleaded guilty to a series of criminal tax charges and paid $\$ 200$ million in fines but Rich remained a fugitive, on the FBI's Most-Wanted Fugitives List, for many years. ${ }^{88}$ Fearing arrest, he did not even return to the United States to attend his father's funeral. ${ }^{89}$ Through his wife he donated more than a

83. Paul J. Larkin, Jr., Revitalizing the Clemency Process, 39 HARV. J.L. \& PUB. PoL'y 833, 847 (2016) ("Under American law, the pardon power is a prerogative that the President can exercise for any reason that he deems just.").

84. See id. at 845 ("Today, the federal and state constitutions generally lodge the clemency power in the hands of the chief executive, whether our president or a governor, and make that power an unchecked prerogative of its recipient.").

85. Id. For more specific examples, see Foley v. Beshear, 462 S.W.3d 389, 392 (Ky. 2015) ("[I]n Kentucky, the decision to grant clemency is left to the unfettered discretion of the Governor." (quoting Baze v. Thompson, 302 S.W.3d 57, 60 (Ky. 2010))), Gore v. State, 91 So.3d 769, 779 (Fla. 2012) ("The Florida Rules of Executive Clemency expressly provide that ' $[\mathrm{t}]$ he Governor has the unfettered discretion to deny clemency at any time, for any reason."), and State v. Castaneda, 84 N.W.2d 740, 758 (2014) ("The Board of Pardons thus has the unfettered discretion to grant or deny a commutation for any reason or for no reason at all.").

86. George Lardner Jr., A Pardon to Remember, N.Y. Times (Nov. 24, 2008), https:// www.nytimes.com/2008/11/22/opinion/22lardner.html; Kelly Phillips Erb, Marc Rich, Famous Fugitive \& Alleged Tax Evader, Pardoned by President Clinton, Dies, ForBEs (June 27, 2013, 12:05 AM), https://www.forbes.com/sites/kellyphillipserb/2013/06/27/marc-richfamous-fugitive-alleged-tax-evader-pardoned-by-president-clinton-dies/\#166703613187.

87. Phillips Erb, supra note 86.

88. Id.; Lardner, supra note 86; Eric Lichtblau \& Davan Maharaj, Clinton Pardon of Rich a Saga of Power, Money, CHI. TRIB. (Feb. 18, 2001, 12:00 AM), https:// www.chicagotribune.com/sns-clinton-pardons-analysis-story.html.

89. Lichtblau \& Maharaj, supra note 88. 
million dollars to President Clinton's reelection campaign and received a pardon in 2001, having never admitted his guilt in the largest tax fraud case in U.S. history. ${ }^{90}$

Maurice Clemmons, an inmate with a long violent history, received a long sentence for a string of violent offenses. ${ }^{91} \mathrm{He}$ had to be shackled during his trial and continued to assault people while in custody. ${ }^{92}$ Despite his continuing misconduct, he was granted clemency by the Governor of Arkansas after serving eleven years of his sentence. ${ }^{93}$ Upon his release, he continued committing violent crimes and in 2009 killed four Washington State police officers. ${ }^{94}$

In a similar case, Thomas Childs, an inmate with a long criminal history including multiple gun charges, four armed robberies, and a violent prison break, was pardoned by the Governor of Massachusetts. ${ }^{95}$ After his release, he continued to have substance abuse problems. ${ }^{96}$ The pardon allowed him to legally own the weapon that he used to kill Kostas Efstathiou, a stranger who Childs felt made an inappropriate remark to his friend's girlfriend and another female friend. ${ }^{97}$

Even if a grant of clemency or pardon is based upon a genuine change in character by the offender, it is problematic because the clemency or pardon can commonly cut off the imposition of punishment deserved for the original offense. As discussed in Part III.C, true redemption cannot

90. Id.; Phillips Erb, supra note 86; Lardner, supra note 86; James V. Grimaldi \& Robert O'Harrow Jr., Fugitive's Pardon Ended 17-Year Effort, WASH. Post (Jan. 28, 2001), https://www.washingtonpost.com/archive/politics/2001/01/28/fugitives-pardon-ended-17year-effort/1c32ddeb-4421-4571-8010-3b04bf77380f/; Arnold H. Lubasch, Marc Rich's Companies Plead Guilty, N.Y. TIMES (Oct. 12, 1984), https://www.nytimes.com/1984/10/12/ business/marc-rich-s-companies-plead-guilty.html.

91. A Path to Murder: The Story of Maurice Clemmons, SEATTle Times (Apr. 12, 2010, 5:30 PM), https://www.seattletimes.com/seattle-news/a-path-to-murder-the-story-ofmaurice-clemmons/.

92. Maurice Clemmons, Man Wanted for Questioning, Has Troubling Criminal History, SeatTle Times (Nov. 30, 2009, 12:59 PM), https://www.seattletimes.com/seattle-news/ maurice-clemmons-man-wanted-for-questioning-has-troubling-criminal-history/.

93. Id.; Documents Relating to the Parole and Clemency for Maurice Clemons, in Zernike, Kate, Old Clemency May Be Issue for Huckabee, N.Y. TIMEs (Nov. 30, 2009), https:/ /www.nytimes.com/interactive/projects/documents/01huckabee.

94. A Path to Murder, supra note 91.

95. Julie M. Cohen, Roslindale Murder Victim's Family Awaits Parole Board's Decision on Killer's Release, WiCKED LOCAL (Sept. 26, 2012, 2:32 PM), https://www.wickedlocal.com/ x670727544/Roslindale-murder-victims-family-awaits-parole-boards-decision-on-killersrelease.

96. See id.

97. Id.; Career Criminal Asking for Freedom 34 Years After Murder of Roslindale Father, Bos. 25 News (Sept. 14, 2017, 7:04 PM), https://www.boston25news.com/news/ career-criminal-asking-for-freedom-34-years-after-murder-of-roslindale-father-1/ $609492676 /$ 
be deserved in the absence of acquiescence in just punishment. Genuine remorse, apology, and making amends may reduce an offender's blameworthiness, but the offender must acquiesce in the punishment that flows from that reduced blameworthiness. Executive clemency and pardon programs that let offenders out early commonly violate this essential principle, while the proposed public redemption program does not.

Because the executive grants of clemency or pardon signal no apology or making amends or acquiescence in just punishment, they fail to serve the needed public-signaling function of reinforcing the shamefulness of the original offense. And because the reasons for the early release may be obscure or unknown, they hardly promote the criminal justice system's moral credibility. More likely, clemency and pardon grants can damage the system's moral credibility because they are commonly seen as one more example of an offender escaping the punishment he or she deserves by getting early release without evidence of remorse or atonement. ${ }^{98}$

The proposed public redemption system may also seem similar to some prisoner reentry programs implemented across the country. In general, those programs aim to facilitate the transition of ex-offenders from incarceration into society, including reentry courts and therapeutic jurisprudence. ${ }^{99}$ Even though the reentry movement is still fragmented, and the countless reentry programs differ from one another in many respects, even in their objectives, target population, and structure, ${ }^{100}$ two characteristics of these programs are similar to the proposed public redemption system. First, both systems operate only after the adjudication and sentencing of the offender; they are not meant to be a substitute for normal criminal adjudication, in the way that restorative justice and transitional justice are. ${ }^{101}$ Second, both the public redemption system and the reentry programs further the reintegration of offenders into society and help them overcome the collateral consequences of criminal conviction and incarceration. ${ }^{102}$

Nonetheless, the public redemption and reentry programs are fundamentally different in many respects. The primary goal of public

98. See Maddy Gates, Rethinking the Use of the Clemency Power, HAR. CIV. RTS. - CIV. LIBERTIES L. REV. (Feb. 12, 2020), https://harvardcrcl.org/rethinking-the-use-of-theclemency-power/.

99. Jessica A. Focht-Perlberg, Two Sides of One Coin - Repairing the Harm and Reducing Recidivism: A Case for Restorative Justice in Reentry in Minnesota and Beyond, 31 Hamline J. Pub. L. \& POL'y 219-21 (2009); Cheryl Lero Jonson \& Francis T. Cullen, Prisoner Reentry Programs, in 44 CRIME \& JUST. 517, 522 (2015).

100. Jonson \& Cullen, supra note 99, at 538; Parker, supra note 70, at 409-16.

101. See Parker, supra note 70, at 409-16.

102. See Focht-Perlberg, supra note 99, at 236-37. 
redemption is to publicly acknowledge offenders who have chosen a path of atonement, whereas a central goal of reentry programs is typically to reduce recidivism and crime rates, and promote public safety. ${ }^{103}$ Moreover, while any offender who meets the criteria discussed above may be entitled to a public redemption, regardless of the nature of his offense or the punishment he received, reentry programs are usually confined to offenders from certain categories, like those with a history of substance abuse, sexual assault, or high risk offenders, 104 and the programs typically focus on offenders who have been incarcerated. ${ }^{105}$ Additionally, unlike public redemption, participating in reentry programs does not require confession, apology, making amends, or acquiescing in deserved punishment, and the participants are often selected solely for falling within the category of offenders targeted by the program, or sometimes based on their score in risk assessment tests. ${ }^{106}$ Further, many of these programs are mandatory and not voluntary. ${ }^{107}$ To the extent that reentry programs assist offenders in making amends and adopting a law-abiding way of life, they may well help an offender toward public redemption.

\section{MAKING THE PUBLIC REDEMPTION DECISION}

Who should make the decision as to whether an offender deserves public redemption, and what should be the procedures for making the decision? Given the nature of the decision, it seems likely that a jury of community members would be most appropriate as decision-makers. Juries tend to be better than judges at fact-finding-perceived as more fair and less biased-and at judgment making, especially normative judgments that will capture the community's views on issues of blameworthiness. ${ }^{108}$

If a jury is to be used, the judicial branch seems the most efficient location for the decision-making body because it can then tap into the existing jury pool system maintained by the judicial branch. Perhaps an

103. See id.; Parker, supra note 70, at 411-13.

104. See Parker, supra note 70, at 409-11.

105. E.g., Second Chance Act of 2007, Pub. L. No. 110-199, 122 Stat. 657 (2008) (codified in scattered sections of 42 U.S.C.) (authorizing federal grants to prisoner reentry services).

106. See Parker, supra note 70, at 409-16.

107. See id. at $416-18$.

108. See Paul H. Robinson \& Barbara A. Spellman, Sentencing Decisions: Matching the Decisionmaker to the Decision Nature, 105 CoLUM. L. REV. 1124, 1138-48 (2005); Verlin B. Hinsz et al., The Emerging Conceptualization of Groups as Information Processors, 121 PSYCH. Bull. 43, 50 (1997); Daniel Gigone \& Reid Hastie, The Impact of Information on Small Group Choice, 72 J. PERSONALITY AND Soc. PSYCH. 132, 139 (1997). See generally Robert J. MacCoun \& Tom R. Tyler, The Basis of Citizens' Perceptions of the Criminal Jury: Procedural Fairness, Accuracy, and Efficiency, 12 L. \& HUM. BEHAV. 333 (1988). 
even stronger argument for locating the decision-making body in the judicial branch stems from the fact that it was the judicial branch that originally imposed the criminal conviction and thus is best suited to determine and announce a finding of public redemption designed to counter the effects of that original conviction.

To further enhance the connection between the original conviction and the subsequent public redemption, it might be appropriate to have a jury of at least the same size as the trial jury, which would typically be twelve jurors. However, there seems no need to have a unanimous verdict in these cases-this is not a decision where a person's life or liberty is at stake. On the other hand, to assure confidence in and credibility of the decision, it may be appropriate to have some kind of super majority requirement of two-thirds or three-quarters. If a super-majority requirement is used, it also might be useful to have a jury larger than twelve, so that the minimum number of jurors required for approval would meet or exceed the twelve jurors who voted for the conviction. For example, if a vote of three-quarters of the jury is required for public redemption, having a jury of sixteen would ensure that at minimum twelve members had voted in favor of any successful grant.

As an alternative to placement in the judicial branch, a governor, probably even without special legislation, could by executive order create such a public redemption mechanism as the means by which he or she exercises the governor's executive clemency or pardon power. Even if the public redemption program were housed in the office of the pardon attorney, or whatever the appropriate executive branch department is, it could still use a jury system rather than leave the decision to executive judgment. Only an independent jury is likely to give the resulting public redemption awards credibility with the larger public. And only a jury of ordinary citizens is likely to promote the long-term credibility of the public redemption awards by weeding out cases that would prove controversial with the general public and thereby risk tarnishing the credibility of all public redemption awards.

How expensive or burdensome would a public redemption hearing be? The public redemption determination process need not be weighed down by the kind of procedural rules that govern a criminal trial. The offender has nothing to fear from the process, and nothing to lose. Neither the offender's liberty nor property are under threat. All that the process is doing is creating the possibility of giving the offender an intangible benefit-public acceptance and redemption. This means that the process need be neither expensive nor cumbersome. Whatever procedures are adopted for the process obviously ought to be applied equally to all applicants. 
The costs of a public redemption procedure ought to be minimal. Because there are essentially no limitations on the kind of information that can be introduced, there is essentially no pre-hearing procedure needed. Because the redemption decision does not require a unanimous verdict, there is no need for the elaborate jury voir dire provided in criminal trials, where a single juror can block a verdict of guilty. 109 The proceeding itself is likely to be something that can be completed in most cases in a few hours. If it is to be placed in the judicial branch, with access to its existing jury assembling system, it will incur little extra cost. In many jurisdictions, jurors spend their days sitting around waiting to be called for trial (and may end up never serving), so these short public redemption hearings can give prospective trial jurors something to do while they are waiting.

Who should be able to present evidence to the redemption jury? Certainly, the offender ought to be free to introduce any relevant evidence. The original office that prosecuted the offense ought to be heard, whether it is in support or in opposition. It seems likely that any offender that satisfies the requirements described above is likely to have the strong support of any fair-minded prosecution office.

It would be appropriate to hear from the victim or the victim's family, although their disapproval ought not to be taken as an effective veto. Again, if the prerequisites described above are satisfied, most victims and victims' families will support the application. On the other hand, it would be easy to understand why someone hurt by the offense might be blinded by their own suffering and unable to fairly assess whether an offender truly deserves public redemption.

It would also be appropriate for community organizations to express their views, but those views ought to be given weight only to the extent that the group has shown itself to be fully aware of the facts of the case and sufficiently fair-minded in judging the propriety of redemption. Groups that will routinely support or those that will routinely oppose all public redemption cases are not likely to provide useful information to the decision-makers. The redemption hearing ought not to be simply a public referendum on the question, which can be heavily influenced by news coverage or strong personalities among those involved. The primary focus must be a fair assessment of whether this offender has shown true remorse and a genuine wish to atone for his or her wrongdoing.

When should a public redemption hearing be held? The application might typically be filed and the hearing held after completion of the deserved punishment. This logically follows from the fact that

109. See generally Herald P. Fahringer, In the Valley of the Blind: A Primer on Jury Selection in a Criminal Case, 43 L. \& CONTEMP. PROBS. 115 (1980). 
acquiescence in the deserved punishment is an essential criterion for granting the application and this acquiescence normally cannot be fully shown until the deserved punishment is complete and without the offender's objection. However, one can imagine situations in which an applicant could persuade a redemption jury that he or she has fully acquiesced-perhaps by legally committing to completing the deserved punishment-so redemption jury might be able to find this requirement satisfied even before the complete conclusion of the term of imprisonment, for example.

On the other hand, as a practical matter, many applicants may have little incentive to pursue an application, even if they were fully qualified to receive public redemption, especially if they will be imprisoned for some time still. But this will not always be the case. Perhaps the offender is anxious to regain a right to vote or escape some other collateral consequence that would have significance even while imprisoned. Perhaps the offender is interested primarily in the symbolic value of gaining public redemption, for the message it sends to friends, family, the victim, and others. Or perhaps the method of punishment used in the offender's case is one that does not involve imprisonment, and therefore the collateral consequences are immediately important to them. There ought to be no fixed rule that limits the timing of the application; the matter should be left to the judgment of the redemption jury in each individual case.

Who may submit a public redemption application? Certainly, any offender who is qualified should be able to submit an application, without exception. There is every reason to also allow and, indeed, encourage third parties to submit an application on behalf of an offender. Such third-party submissions are valuable and ought to be encouraged. A truly remorseful offender may not be spending time thinking about public recognition and escaping collateral consequences. ${ }^{110}$ Also, given the mixed reputation of the criminal justice system in some quarters, ${ }^{111}$ some deserving offenders may assume their applications will not be fairly judged, such that there is no point submitting. As a result, many deserving cases may never be recognized, unless third parties discover them and make applications for them. By doing so, such organizations would be promoting not only the offenders' individual interests, but also

110. As Murphy notes, a remorseful offender may have "neurotic desires for too much self-punishment." MURPHY, supra note 37, at 52.

111. See 91 Percent of Americans Support Criminal Justice Reform, ACLU Polling Finds, ACLU (Nov. 16, 2017), https://www.aclu.org/press-releases/91-percent-americans-supportcriminal-justice-reform-aclu-polling-finds. 
the larger societal interests that a stream of public redemptions would promote.

\section{Two Kinds OF POLITICAL OPPOSITION}

One might initially assume that such a public redemption program would be welcomed by all, with only minor disputes about the details of its criteria and procedures. After all, it takes nothing away from what all parties have in the current system. It simply provides an additional path that a convicted offender might follow if he or she chose to do so, with no pressure or penalty of any sort for not choosing to pursue a path of public redemption. At the same time, it would seem that any reasonable person would approve the propriety of awarding public redemption in a case where the prerequisites suggested here are satisfied: the redeemed offender has truly earned such recognition, there is no obvious cost to giving it, and everything to gain by doing so. Such a system can provide a series of uplifting and educational positive examples that can inspire other offenders-and us non-offenders as well.

But political reality is more complicated. The difficult and distorted nature of American crime politics will have its effect, ${ }^{112}$ and the two competing sides will each have their own objections.

The anti-punishment school will want to water down whatever requirements there are for public redemption, so as many people as possible can escape the collateral consequences of a conviction. ${ }^{113}$ It may not matter that the proposal provides an opportunity not otherwise available for those offenders who want to choose this path. This school will insist on weakening the criteria because they are untouched by notions of remorse, atonement, or redemption. They have effectively disconnected the criminal justice system from notions of morality or desert and see it instead as a game of manipulation in which their goal is to minimize punishment.

But this sort of corner-cutting-watering down the prerequisites for public redemption in order to maximize the number of persons who can escape collateral consequences-is likely to endanger the efficacy of the entire project and, ultimately, its existence. The public announcement in celebration of redemption can only achieve its official redeeming purpose if it is, in fact, reserved for cases that truly deserve it. Giving such public acclaim to cases that do not serve only to "dilute the brand," which means

112. See Paul H. Robinson \& Michael T. Cahill, The Accelerating Degradation of American Criminal Codes, 56 Hastings L.J. 633 (2005); Paul H. Robinson, The Rise and Fall and Resurrection of American Criminal Codes, 53 U. LouisviLle L. REV. 173 (2015).

113. See Margaret Colgate Love, Paying Their Debt to Society: Forgiveness, Redemption, and the Uniform Collateral Consequences of Conviction Act, 54 How. L.J. 753, 753 (2011). 
those who deserve the public recognition, and the corresponding difference in treatment, will not get the relief that they deserve. Indeed, as a political matter, it seems unlikely that one could politically sustain the withdrawal of collateral consequences if used in undeserving cases. It may be one thing to announce public redemption for somebody who does not deserve it, for the damage to those who do deserve it may not be obvious. But the suspension of collateral consequences for those who do not deserve it will be much more obvious and, in some cases, probably tragic.

The law-and-order school, on the other hand, may be opposed to the public redemption proposal for opposite reasons. Their inclination is to maximize punishment on criminal wrongdoers. ${ }^{114}$ Once an offender is convicted, they are likely to object to the removal of collateral consequence for any reason. To do so is "being soft on crime."115 Also driving their objection to the proposal will be their tendency to focus upon the objective harms of the offense, with little attention to subjective culpability requirements and even less to mitigating circumstances. Thus, they may well object to the notion that an offender's deserved punishment may be reduced by genuine remorse, apology, and a true desire to atone.

But these sorts of objections only serve to injure this school's claimed goal of doing justice. If one believes in the importance of doing justice, one must appreciate that this means diligently tracking an offender's deserved punishment by taking full account of all facts relevant to the desert, both objective harms and subjective culpability requirements, both aggravations and mitigations. ${ }^{116}$ The facts relevant to the desert are not unknowable or matters of hopeless disagreement. Empirical research has shown that ordinary people, no matter their level of education or other demographic, have sophisticated and nuanced judgments of justice that can be measured and reduced to operating principles. ${ }^{117}$ If the empirical evidence shows that the proposed prerequisites for public redemption in fact reduce an offender's perceived blameworthiness as perceived by ordinary people, as noted previously, 118 then this school's commitment to justice demands that they take these factors into account in assessing punishment.

114. See Anthony M. Platt, The Politics of Law and Order, 21 Soc. JusT. 3, 8-9 (1994).

115. See id. at 4.

116. Paul H. Robinson, Mitigations: The Forgotten Side of the Proportionality Principle, 57 HARV. J. ON LEGIS. 219 (2020).

117. INTUITIONS OF JUSTICE, supra note 65, at 239-412.

118. See supra notes 57-59 and accompanying text. 
Under the proposed criteria, we can be sure that public redemption will not be granted unless justice has already been done. Thus, to insist on additional punishment by denying release from the collateral consequences of conviction is, by definition, to insist on unjust punishment. ${ }^{119}$ Insistence on punishment beyond what is deserved ought to be anathema to those devoted to the importance of doing justice.

\section{SUMMARY AND CONCLUSION}

The criminal justice system traditionally performed its public functions-condemning criminal conduct, shaming and stigmatizing violators, promoting societal norms-through the use of negative examples: convicting and punishing criminal offenders. One could imagine, however, that the same public functions could also be performed through the use of positive examples: publicly acknowledging and celebrating offenders who have chosen a path of atonement through confession, apology, making amends, acquiescing in just punishment, and promising future law-abidingness. An offender who takes this path arguably deserves public recognition, an update of all records and databases to show this public redemption, and an exemption from all collateral consequences of conviction.

Ideally, such a public redemption decision should be made by a jurylike body located in the judicial branch, with the finding of public redemption announced with the same publicity and solemnity as a criminal conviction. However, it seems likely that there will be political objections to such a system from both the anti-punishment school and the law-and-order school, making legislative creation of such a program complicated. It may well be that the first of such programs can best be pioneered by governors who adopt the proposed system of public redemption as the official mechanism by which the executive's clemency and pardon power is exercised.

Our criminal justice history has been almost exclusively based upon advertising the negative example of conviction and punishment as the means by which we condemn prohibited conduct, stigmatize violators, and promote societal norms. Perhaps it is worth at least experimenting with a system of positive examples to promote these same important goals.

119. One might argue that the collateral consequences of conviction and the shame and stigma that an offender would avoid by an award of public redemption are not officially forms of "punishment." But to the extent that they are imposed by the state as a result of the offender's criminal conviction, and they carry some form of suffering, why shouldn't they be taken into account in satisfying the total amount of punishment an offender deserves? 